\title{
THE UNITED NATIONS'APPROACH TO TRADE, THE ENVIRONMENT AND SUSTAINABLE DEVELOPMENT
}

\author{
Shawkat Alam*
}

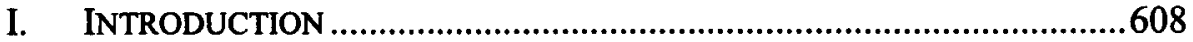

II. THE EMERGENCE OF TRADE AND THE ENVIRONMENT IN THE

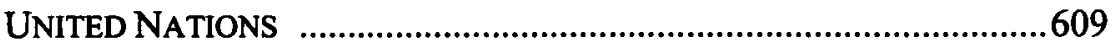

III. THE UN CONFERENCE ON THE HUMAN ENVIRONMENT ...................610

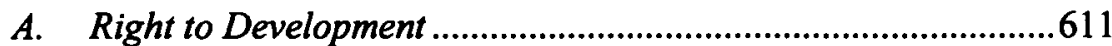

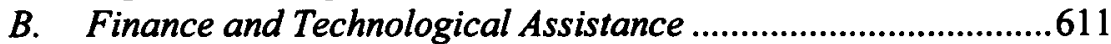

C. Commodity Prices ..................................................................612

D. The Special Situation of Developing Countries........................612

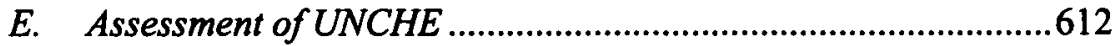

IV. THE UNITED NATIONS ENVIRONMENT PROGRAM .........................615

A. Funding Issues in UNEP ...................................................615

B. Issues with the Political Legitimacy and Legal

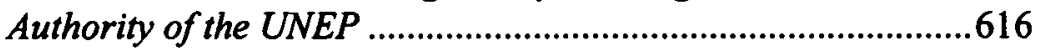

C. Geographical Isolation of the UNEP .....................................617

V. THE U.N. CONFERENCE ON ENVIRONMENT AND

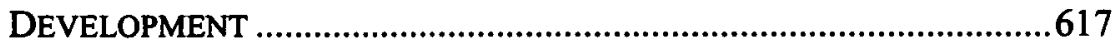

A. The Rio Declaration on Environment and Development (The Earth Charter) ....................................................................618

B. The United States and the Rio Declaration ..............................619

C. Assessment of the Rio Declaration ..........................................620

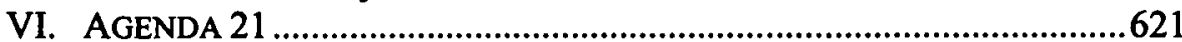

VII. AN ASSESSMENT OF THE RIO DECLARATION AND AGENDA 21: RHETORIC AND REALITY ..........................................625

A. Lack of Specificity in Agenda 21 Commitments ......................625

B. Lack of Financial Resources (Agenda 21, Ch. 33)...................626

C. Transfer of Technology (Agenda 21 Ch 34) ............................627

D. Capacity Building (Rio Principle 12, Agenda $212.38(a-c))$.

E. Green Protectionism (Rio Principle 12;

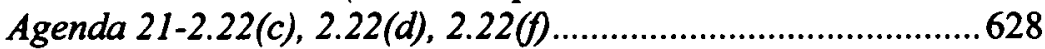

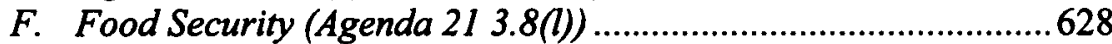

G. Conclusions on the Rio Declaration and Agenda 21.................628

* $\quad$ LLB (Honores), LLM, PhD; Conferenciante, Centro de Derecho Ambiental, Facultad de Derecho, Macquarie University, Sydney, Australia. Correo electronico: shawkat.alam@law.mq.edu.au. 
VIII. NORTH-SOUTH ASPECTS OF THE UNITED NATIONS

APPROACH TO TRADE AND THE ENVIRONMENT

A. Lack of Financing and Systematic Unfairness in the

Global Economic Order.

B. The Concept of Common but Differentiated

Responsibility.

1. Developed Countries are the Larger Polluters...................632

2. Capacity to Pay..........................................................632

3. Unsustainable Consumption Patters of the North .............632

C. The Polluter Pays Principle and Developing Countries ...........632

D. The Intergenerational and Intragenerational

Equity Principles .633

E. The Precautionary Principle

F. Trade-Related Environmental Measures (Rio Principle

12; Agenda 21 2.22(i), 39.3 (d)).

G. Traditional Intellectual Property Rights

(Agenda 21 15.4(g))

H. Biodiversity and Forest Conservation .637

IX. CONCLUSION 638

\section{INTRODUCTION}

The complex and transboundary nature of current environmental problems has turned them into global issues that intricately link ecology, economics and politics. The sectoral and fragmented development of institutions to address these global problems has been unable to keep pace with the increasing interdependence of the economy and ecology. There is an incongruity between the problems which arise from the interconnected nature of the global ecosystem, and their solutions, which are sought in the framework of a geopolitical system based on the sovereign State. ${ }^{1}$

Global environmental problems warrant global solutions on a multilateral basis. Thus, any national effort to address these issues without a support network of international institutional instruments and principles is likely to be ineffective. Furthermore, any individual organization or actor is further prevented from responding to environmental needs because of the overriding North-South dynamics of the problem.

The United Nations (hereinafter "UN") is exceptionally well positioned for addressing these issues. The UN is the only multilateral organization that possesses universal membership and is global in its scope. It can better help governments in their environmental protection initiatives because of its multidisciplinary capabilities and broad experience involving 
all stakeholders in the trade and environment regimes. ${ }^{2}$ The UN continually strives to achieve international cooperation and support for capacity building in trade, environment and development in the South. The UN, through its many specialized agencies, also carries out work and reporting on the development of a framework to integrate trade and environmental policies by taking into account the special needs of developing countries. In addition, the UN process has offered developing countries, despite their weaker bargaining power, an opportunity to participate effectively in negotiations in which industrialized nations have had to make considerable concessions. ${ }^{3}$

Part II of this article will provide a brief summary of the emergence of environmental concerns in the UN, and the ways in which members sought to link these concerns with international trade issues. Part III will outline the role of the first UN organization to deal explicitly with trade and environment issues, the UN Conference on the Human Environment. One of the key outcomes of this conference, the UN Environment Program will be discussed in Part IV. The contribution of the 1992 UN Conference on Environment and Development to trade and environment issues will be discussed in Part V. Part VI will look at key outcomes of this conference, including Agenda 21 and the Rio Declaration, and Part VII will provide a critique of both of these documents. Finally, Part VII will analyze some important issues for developing countries in the UN's approach to trade and the environment.

\section{THE EMERGENCE OF TRADE AND THE ENVIRONMENT IN THE UNITED NATIONS}

Environmental protection was not an issue on the UN agenda when it was established over 50 years ago and so the UN was not given a specific mandate to address issues concerning the environment. The UN has, however, carved out a role for itself in this area by widely interpreting its preamble and other articles which promote economic and social well-being. These principles are primarily concerned with the issues of health, development and education. Examples of these widely interpreted principles include Articles 1(4) and 3 of the preamble to the Charter of the UN. ${ }^{4}$ Also, under Article 55, the UN is required to promote higher standards of living, full employment and the conditions for economic and social progress and development. ${ }^{5}$ Article 55 also states that the UN should endeavor to

2. Id. at 95 .

3. Rubens Ricupero, UNCED and Agenda 21: Chronicle of a Negotiation, 4 CoLO. J. INT'L ENVTL. L. \& POL'Y 1, 81, 95 (1993).

4. U.N. CHARTER art. 1(4), para. 3.

5. Id. art. 55. 
provide solutions to international economic, social, health, and related problems, as well as international cultural and educational cooperation. ${ }^{6}$

\section{THE UN CONFERENCE ON THE HUMAN ENVIRONMENT}

The year 1972 marked a turning point in the UN's role in the protection of the world environment. ${ }^{7}$ The UN Conference on the Human Environment (hereinafter "UNCHE"), held in Stockholm in that year, was the first all-encompassing international conference on the environment, and it led to the creation of the first subsidiary body of the UN focusing on the protection of the environment. ${ }^{8}$ This was the United Nations Environment Program (hereinafter "UNEP"). ${ }^{9}$

Three main topics provided the basis for the Stockholm conference: the planning and management of human settlements; natural resources and aspects of development, which could be seen to include developing countries; and the identification and control of pollutants. ${ }^{10}$ The most important instruments that emerged from the UNCHE are the various action plans, and the "Stockholm Declaration.""

Trade and environment issues emerged in that UNCHE in the context of competitiveness concerns associated with the trade and environment interactions. $^{12}$ One example of this concern is that where one country moved vigorously to establish strong environmental protection through pollution taxes, effluent and emission standards or otherwise, its competitive position within the international community may suffer. ${ }^{13}$ As a result, there would be little economic incentive for individual states to undertake environmental protection measures.

Also expressing concern about the identification and control of pollutants, the UNCHE drew attention to environmental protection as an international concern and accordingly put the environment on the international agenda. Developing countries, however insisted that the

6. Id.; see also Patricia Bimie, Environmental Protection and Development, 20 MELB. U. L. REV. 66, 68 (1995).

7. Birnie, stupra note 6 , at 69 .

8. Id. at $69-70,81$.

9. Id. at 70,81 .

10. Id. at 81 .

11. United Nations Conference on the Human Environment, Stockholm, Sweden, June 5-16, 1972, U.N. Doc AVCONF.48/14/Rev.1 [hereinafter Stockholm Declaration].

12. Charles S. Pearson, The Trade and Environment Nexus: What is New Since '72?, in Trade and the ENVIRONMENT LAw, Economics, AND Policy 23, 24 (Durwood Zaelke et al. eds., 1993).

13. Id. 
environmental problems facing them should be defined in a way that takes into account their need for economic development.

This section will now outline the ways in which the trade-environment issue is addressed in the Stockholm declaration.

\section{A. Right to Development}

In paragraph four, the Stockholm Declaration recognized that "developing countries must direct their efforts to development bearing in mind their priorities and the need to safeguard and improve the environment." 14 It also stated that developed countries should "make efforts to reduce the gap between developing countries and themselves."15 It would seem, therefore, that the declaration recognizes that the protection of the environment is a common responsibility, and also that developed countries have an obligation to both improve their own environmental practices, as well as provide assistance to developing countries so that they can improve theirs. It noted that "in the industrialized countries, environmental problems are generally related to [the process of] industrialization and technological development."16

In its Principle 11, the Stockholm Declaration warned against the negative effect of any environmental measures on the development prospects of developing countries. ${ }^{17}$ It specifically stated that "environmental policies of all States should enhance and not adversely affect the present or future development potential of developing countries."18 It also states that an agreement should be reached on "meeting the possible national and international consequences resulting from the application of environmental measures."19

\section{B. Finance and Technological Assistance}

The Stockholm Declaration stressed the need for the provision of financial and technological assistance to developing countries to enable them to address their environmental problems. ${ }^{20}$ The situation of developing countries in this context was characterized as:

14. Stockholm Declaration, supra note 11, para. 4.

15. Id.

16. Id.

17. Id. princ. 11 .

18. Stockholm Declaration, supra note 11, princ. 11.

19. Id.

20. Id. princ. 9 . 
Environmental deficiencies, generated by the conditions of underdevelopment and natural disasters, pose grave problems and can best be remedied by accelerated development through the transfer of substantial quantities of financial and technological assistance as a supplement to the domestic effort of the developing countries. ${ }^{21}$

\section{Commodity Prices}

Developing countries are heavily dependent on commodity exports for their revenue. ${ }^{22}$ As a result, continued declines in the price of commodities are likely to adversely affect the capacity of developing countries to address issues of sustainable development. ${ }^{23}$ Principle 10 of the Stockholm Declaration recognizes this issue, and states that the stability of commodity prices "are essential to environmental management."24 This is because, in order to create sustainable development strategies, "economic factors, as well as ecological pressures must be taken into account." 25

\section{The Special Situation of Developing Countries}

The special situation and needs of developing countries - in addition to international technical and financial assistance have been recognized in Principle 12 of the Stockholm Declaration which states that "resources should be made available . . . taking into account . . . any costs which may emanate from their [incorporation of] environmental safeguards into their development planning." ${ }^{26}$ However, trade related environmental measures and environment-related trade measures do not seem to have emerged at that point in time.

\section{E. Assessment of UNCHE}

UNCHE was the first comprehensive attempt to address environmental issues on a global scale. Although the Declaration is not binding upon states, it was unanimously adopted by the 113 Nations constituting the UN General Assembly. ${ }^{27}$ The adoption of the existing legal principles reflects

21. Id.

22. Id. princ. 10.

23. Stockholm Declaration, supra note 11, princ. 10.

24. Id.

25. Id.

26. Id. princ. 12.

27. Principle 21 of the Stockholm Declaration affirmed an existing international legal obligation which reads as follows: 
the political and moral aspirations of governments with regard to the preservation and improvement of the human environment. ${ }^{28}$ In fact, the Stockholm Declaration has "received broad-based recognition and acceptance in the International Community as a result of the fundamental nature of the values expressed.",29

Although the Stockholm Declaration showed a general recognition of the need for international action in the sphere of the environment, and outlined a scheme designed to ensure effective environmental management, many argue that the Stockholm Conference merely "represented a compromise rather than a consensus . . . since universal agreement between developing and developed countries was difficult to achieve in most areas." 30 While the Stockholm Declaration was confined to the human environment, developing countries attempted to link it to development. For the South, environmental problems are likely to be interlinked with developmental problems and questions of distributive justice.

The output from Stockholm also tended to be heavily rhetorical, and "[the] ambiguous compromises among conflicting ideologies ... . have increasingly become vehicles for the complaints of the developing against the developed nations." 31 For example, principle 21 explicitly mentioned the responsibility of the state to avoid or prevent any damage to the environment in any other state or area beyond its national jurisdiction. ${ }^{32}$ However, no instrument or procedure to enforce states obligations under the declaration was set in place. It would appear that there was some uncertainty about the ability of the relevant governments to carry out this responsibility.

Also noteworthy is the unlimited sovereign right each state was given to exploit their own resources in accordance with their own environmental

States have, in accordance with the Charter of the $\mathrm{UN}$ and the Principles of International law, the sovereign right to exploit their own resources and the responsibility to ensure that activities within their jurisdiction or control do not cause damage to the environment of other states or of areas beyond the limits of national jurisdiction.

Id. princ. 21.

28. Marc Pallamaerts, International Environmental Law From Stockholm to Rio: Back to the Future?, in GREENING INTERNATIONAL LAw 1-19 (Phillipe Sands ed., 1993).

29. Tony Simpson and Vanessa Jackson, Human Rights and the Environment, ENV'T \& PLAN. L.J. 268, 271 (1997).

30. Ved P. Nanda, Trends in International Environmental Law, 20 CAL. W. INT'L L.J. 187, $189-90(1989-90)$.

31. Lynton Keith Caldwell, international environmental Policy-Emergence AND DIMENSIONS 51 (1984).

32. Stockholm Declaration, supra note 11, princ. 21. 
policies. This "right" continues to raise problems associated with deeper issues with the concept of state sovereignty.

During the organization of the Conference agenda, it would seem that the most pressing issues were deliberately avoided. As a result, the matters that most nations preferred to avoid, such as the dynamics of the human population, the mismanagement of economic development programs and the indirect threat of militant ideologies to the global environment, were not major agenda items. ${ }^{33}$ A significant item contained within the Stockholm Declaration is Principle 22, stated that "States shall cooperate to develop further the international law regarding liability and compensation for the victims of pollution and other environmental damage caused by activities within the jurisdiction or control of such States to areas beyond their jurisdiction.",34

This issue of liability and compensation, although taking shape at Stockholm, remains only a point of controversy as the international community made no firm commitment to the application of a particular standard at the time. ${ }^{35}$

The principle of compensation belongs to a set of propositions later formalized by the UN General Assembly in the Declaration on a New International Economic Order. ${ }^{36}$ While the recommendation was debated at length, it did not result in action because of wide-spread opposition from developed countries. ${ }^{37}$ Conventions dealing with environmental incidents have deliberately skirted the liability issue, often taking the form of a commitment by states to articulate standards of liability without actually prescribing any such standards. ${ }^{38}$ Although the Stockholm Conference and those following it did raise international awareness and concern about environmental deterioration there was a failure to "implement internationally formulated promises."39

33. CALDWELL, supra note 31 , at 55 .

34. Stockholm Declaration, supra note 11, princ. 22.

35. Winfried Lang, Environmental Protection: The Challenge for International Law, $20 \mathrm{~J}$. WORLD TRADE L. 5, 489, 490 (1986).

36. CALDWELL, supra note 31 , at 58. See also Stockholm Declaration, supra note 11, recommendation 103 (b) which states that the essence of the compensation issue "where environmental concerns lead to restrictions on trade, or to stricter environmental standards with negative effects on exports, particularly from developing countries, appropriate measures for compensation should be worked out within the framework of existing contractual and institutional arrangements."

37. CALDWELL, supra note 31 , at 58.

38. Richard E. Levy, International Law and the Chernobyl Accident: Reflections on an Important but Imperfect System, 36 U. KAN. L. REV. 81,99 (1987-88).

39. Ranee Khooshie Lal Panjabi, From Stockholm to Rio: A Comparison of the Declaratory Principles of International Environmental Law, 21 DENV. J. INT'L L. \& POL'Y 215, 216 (1993). 


\section{THE UNITED NATIONS ENVIRONMENT PROGRAM}

The UNEP, the first UN agency designed to coordinate the goals of global environmental assessment and management, was the most significant outcome of the Stockholm Conference. The UNEP has been responsible for supporting numerous soft law instruments, and has particularly focused on the inadequacies of existing legal instruments. As a result, it has sought to develop a more effective international legal regime. ${ }^{40}$

However, the UNEP has been given the responsibility for global environmental governance without being given any real authority to ensure its effective operation. Although the scope and severity of the threats to the global environment have proved to be greater than ever before, both the authority of the UNEP, and its capacity to address these threats are extremely limited. ${ }^{41}$ With a modest and declining budget, the constituent instruments that established it and its geographical location in the Third World have combined to make it difficult to carry out the functions for which it was established.

\section{A. Funding Issues in UNEP}

The funding of the UNEP is provided by the voluntary and convenient contributions from the member states of the General Assembly, and also out of the regular UN budget. ${ }^{42}$ Both the voluntary contributions and the support from the UN budget have been gradually shrinking, with the result that the UNEP suffers severe financial crises on a regular basis. ${ }^{43}$ As a result, "the UNEP budget is simply too low to meet the needs of dealing with the increasingly complex and growing list of environmental challenges.' 14

It would also seem that long-debated North-South issues have contributed to a portrayal of the UNEP as the captive of developing countries. This is because the developed countries have no real control over its activities. The tactical victory of developing nations on setting priorities for the UNEP has threatened to jeopardize the financial and political support to the organization from developed countries. ${ }^{45}$ Nevertheless, the member

40. Phillippe Sands, Principles of International Environmental Law, Vol. 1, 72 (1995).

41. David Hunter et al., INTERNATIONAL ENVIRONMENTAL LAW AND POLICY 396 (1998).

42. Id. at 392.

43. Id.

44. United Nations, Governing Council of the United Nations Environment Programme, Twenty-Third Session of the Governing Council/Global Ministerial Environment Forum, North American Regional Civil Society Statement to the Sixth Global Civil Society Forum, UNEP/GC/INF16/Add.5 (2004).

45. CALDWELL, supra note 31 , at 62. 
states of the UN must address the financial crisis faced by UNEP if they want to see UNEP as the catalyst for a widening sphere of activities for the promotion and protection of the global environment.

\section{B. Issues with the Political Legitimacy and Legal Authority of the UNEP}

Although the UNEP was established to further international environmental diplomacy, as well as the future development of international environmental law, it was not created with a positive attitude or given any real strength to carry out those objectives. Political factors have caused uncertainty about its authority and power. Developed countries did not wholeheartedly want an organization of this kind, which would inevitably involve providing financial support while the organization serves the interests of developing countries. Developing countries on the other hand are reluctant to accept an institution whose decisions might place restrictions on their development.

Other UN agencies have also been intent on jealously guarding their existing environment-related prerogatives. ${ }^{46}$ The UNEP is often perceived by specialized UN agencies as the representative of a special sectoral interest to which appropriate attention should be paid, rather than as a coordinating body intended to ensure the presence of environmental sensitivity throughout the UN system. ${ }^{47}$

The UNEP also has no authority to enforce an environment-related program, which makes it almost impossible for the UNEP to function as a unilateral entity with the authority to impose mandatory rules. The UNEP also does not even seem to have any influence over the UN's other agencies. ${ }^{48}$ Organizations such as UNDP and the World Bank have shown little interest in examining the environmental consequences of their projects or setting up projects following UNEP guidelines. ${ }^{49}$ For example, the World Bank in 2003 adopted the Equator Principles with a view to determining, assessing and managing projects in a socially manageable and environmentally sustainable manner. ${ }^{50}$ The UNEP does not seem to have any power or authority to supervise the implementation and enforcement of the Principles. ${ }^{51}$

\footnotetext{
46. ELLIOT, supra note 1, at 12.

47. CALDWELL, supra note 31 , at 71 .

48. Id.

49. Id.
}

50. The "EQUATOR PRINCIPLES": AN INDUSTRY APPROACH FOR FINANCIAL INSTITUTIONS IN Determining, Assessing and Managing ENVIRonmental \& Social Risk IN Project FInANCING (2003), available at http://www.equator-principles.com/principles.shtml (last visited Mar. 17, 2006).

51. Id. 


\section{Geographical Isolation of the UNEP}

Setting up UNEP's headquarters in Nairobi was a compromise in favor of the Third World. Soon after its establishment, it was realized that its geographical position placed it in virtual isolation from international diplomacy and even from the UN system. This geographical isolation has further complicated UNEP's communication and coordination with other UN organizations, states, and its contact with the scientific community and environmental movements.

The UNEP and its relationship with Multilateral Environmental Agreements and the Commission on Sustainable Development need to be strengthened and clearly defined in order to avoid jurisdictional conflicts and inconsistencies.

\section{THE U.N. CONFERENCE ON ENVIRONMENT AND DEVELOPMENT}

In 1992, the UN Conference on Environment and Development (hereinafter "UNCED") provided a significant forum for the debate about trade and environmental issues, and their relationship to sustainable development. ${ }^{52}$ This conference was the outcome of the December 22, 1989 United Nations Conference on Environment and Development General Assembly Resolution, which insisted on a global meeting that would "devise strategies to halt and reverse the effects of environmental degradation in the context of increased national and international efforts to promote sustainable and environmentally sound development in all countries." 53

At UNCED, the world community sought to strike a balance between trade and environment by defining their relationship to sustainable development. Developed countries wanted to have the environment on the agenda while developing countries were primarily concerned with their own development and economic growth. Developed and developing countries struck a bargain at Rio in which developing countries agreed to support Multilateral Environmental Agreements ${ }^{54}$, and to adopt and enforce the appropriate environmental legislation domestically. At the same time, developed countries promised to help developing countries by assisting their capacity building efforts, providing increased financial resources,

52. See generally Report on the United Nations Conference on Environment and Development, June 3-14, 1992, Annex I, U.N. Doc. ACONF.151/26 (Vol. D [hereinafter Rio Declaration].

53. G.A. Res 44/228, U.N.GAOR, 44th Sess., §§ 1.13, 1.15(d) (1989).

54. See, e.g., Convention on Biological Diversity, June 5, 1992, 1760 U.N.T.S. 79 (entered into force Dec. 29, 1993) and United Nations Framework Convention on Climate Change, May 9, 1992, 1771 U.N.T.S. 107. 
transferring technology, reducing trade protectionism, and by looking into the trade problems of developing countries.

\section{A. The Rio Declaration on Environment and Development (The Earth Charter)}

The Rio Declaration was one of the major documents signed at the Earth Summit. ${ }^{55}$ It determined the rights and responsibilities of states in the process of achieving sustainable development, and reflected the international community's recognition of the fact that long-term economic development cannot be isolated from the need for environmental protection. $^{56}$ It also set out a new formula that recognized that economic development must be sustainable in order to be both equitable, and to protect the natural resource base. ${ }^{57}$ At least in principle, the Rio Declaration integrated the aspirations of both developed and developing countries. ${ }^{58}$ It provided a balance between the North and the South by addressing their key concerns. 59 It recognized that the eradication of poverty is an indispensable requirement of sustainable development. ${ }^{60}$ The special needs of developing countries including the promotion of a supportive and open international economic system were also enshrined in the Rio Declaration. ${ }^{61}$

Principle 3 of the Declaration, like the UNCHE, recognized the "right to development," and noted that this right must be fulfilled in a way that meets the developmental and environmental needs of present and future generations. $^{62}$ Developing countries have long insisted that their right to development cannot be sacrificed for the protection of the environment. The special situation and needs of developing countries were considered to be a high priority. Principle 7 stresses that states have a common but differentiated responsibility to pursue sustainable development. ${ }^{63}$ In this principle, developed countries acknowledged the responsibility that they bear in the international pursuit of sustainable development in view of the pressures their societies place on the global environment, and the technologies and financial resources they command. ${ }^{64}$ This common but

55. See generally Rio Declaration, supra note 52.

56. Id.

57. Id.

58. Id.

59. Id.

60. Rio Declaration, supra note 52.

61. Id.

62. Id. princ. 3 .

63. Id. princ. 7 .

64. Id. 
differentiated responsibility principle imposes an obligation upon the North to provide resources to the South so that they may achieve sustainable development. ${ }^{65}$ The South has argued that they could contribute to sustainable development if the North would give them the necessary resources to do so. The Rio Declaration reiterated the responsibility that all states have to cooperate to strengthen capacity building for sustainable development through the exchange of scientific and technological knowledge and the transfer of new and innovative technologies. ${ }^{66}$

Principle 12 of the Rio Declaration emphasized the necessity of the reciprocal coexistence of trade and environment in the promotion of sustainable development. ${ }^{67}$ It stated specifically that "trade policy measures for environmental purposes should not constitute a means ... [of] disguised restriction on international trade. ${ }^{.68}$ It also asserted that "unilateral actions to deal with environmental challenges outside the jurisdiction of an importing country should be avoided. ${ }^{.69}$ As a result, the only time when environment-related trade measures would be justifiable is where the environmental issue in question is transboundary or global in nature. ${ }^{70}$ Even when this is the case, the decision to apply trade measures should only occur upon an "international consensus." 71

This principle reflects the sentiments of developing countries regarding trade-related environmental measures which have the potential to be used as protectionist measures. This fear would not appear to be without foundation. On many occasions, developed countries have unilaterally imposed trade sanctions on goods from developing countries in the name of environmental protection. ${ }^{72}$

\section{B. The United States and the Rio Declaration}

Although the Rio Declaration was an unbracketed text which was accepted universally, in the last plenary session the United States (US) issued a written statement listing its formal reservations about the Rio Declaration. ${ }^{73}$ In particular, some of these reservations included Principle 3

65. Rio Declaration, supra note 52, princ. 7.

66. Id. princ. 9.

67. Id. princ. 12.

68. Id.

69. Id.

70. Rio Declaration, supra note 52.

71. Id.

72. See infra Part XIII (discussing the precautionary principle, and its use by the European Communities in the "North-South").

73. INT'L ENVTL. LAW AND POLICY SERIES, THE EARTH SUMMIT: THE UNITED NATIONS CONFERENCE ON ENVIRONMENT AND DEVELOPMENT (UNCED) 117 (1993). 
(which was concerned with the right to development), Principle 7 (the US rejected any interpretation that would imply a recognition of or acceptance by the US of any international obligations or liabilities, or any diminution in the responsibilities of developing countries), and Principle 12 (the US insisted that in certain situations, trade measures may provide an effective and appropriate means of addressing environmental concerns). ${ }^{74}$ Throughout the negotiations, the US consistently played a negative role, and was determined to avoid commitment. During the final pre-Rio preparatory conference, the instructions to US representatives were widely known within the delegation as the "ten commandments." 75 These were:

[D]on't make any commitments; don't accept the transfer of technology, the need for new institutions, requests for new financial resources, the need for environmental impact assessments, US liability for the environmental problems of developing nations, the precautionary principle, the need for dispute resolution, the need for new financial assessments; and don't mention the military. ${ }^{76}$

\section{Assessment of the Rio Declaration}

The Rio Declaration was not intended to be binding upon states. Instead, the language used in the declaration suggested courses of action, as opposed to prescribing what should constitute appropriate behavior. The use of the word "should", as opposed to "shall" in the Declaration seems to indicate that the declaration was not intended to be particularly assertive. ${ }^{77}$ In addition, it would appear that there was insufficient momentum or political will at UNCED to move these principles into a global convention. The principles thus remain principles only.

The Rio Declaration, without any accompanying broad framework of action, improved very little on the Stockholm Declaration of $1972 .^{78}$ The Rio Declaration has been characterized by Malanczuk as a "cumbersome compromise between North and the South which avoids addressing the real North-South controversies."79 This reflects the "continuing dissent on the

74. Id.

75. Sherwood F. Rowland, Failure at the Earth Summit, SCIENCE, May 22, 1992, at 1109.

76. Id.

77. See generally Rio Declaration, supra note 52.

78. Stockholm Declaration, supra note 11.

79. Ben Boer, The Globalisation of Environmental Law: The Role of the United Nations, 20 MELB. U. L. REV. 101, 105 (1995). 
fundamental objectives of sustainable development, and the means of their implementation."

However, the Rio Declaration cannot be considered an end in itself. Its success depends on the commitment of governments and other actors to make the Rio principles operational at global, regional, national and local levels. Although linkage between the environment and development was recognized in the Rio Declaration and in Stockholm, little progress was made towards real integration of the environment and the development process. While evaluating the outcome of Rio, Ashok Khosla rightly pointed out that "the operation was a success but the patient's health has not improved."81

\section{AGENDA 21}

Agenda 21 was adopted by the 178 parties of the UNCED. ${ }^{82}$ It was designed to provide a comprehensive plan of action in every area of humanity's interaction with the environment. ${ }^{83}$ In Part A, Chapter 2 of Agenda 21, the international community is called upon to "ensure that environmental and trade policies are mutually supportive, with a view to achieving sustainable development, a development which is socially equitable and protective of the natural resource base." the development process would not gain momentum if developing countries were weighed down by external indebtedness, a lack of developmental finance, the persistence of barriers to market access, and if commodity prices and terms of trade in developing countries remained depressed. ${ }^{85}$

This section will outline the ways in which chapter 2 of Agenda 21 manifested the trade, environment and sustainable development linkage in four main programme areas.

80. Peter Malanczuk, Sustainable Development: Some Critical Thoughts in the Light of the Rio Conference, in SUSTAINABLE DEVELOPMENT AND GOOD GOVERNANCE (Konrad Ginther et al. eds., 1995).

81. Ashok Khosla, The Road from Rio to Johannesburg, in THE MILLENNIUM PAPERS 6 (Beth Hiblin ed., 2001), available at http:/www.earthsummit2002.org/mill\%20paper5.pdf (last visited Oct. 8, 2005).

82. United Nations Conference on Environment and Development, Rio de Janeiro, Brazil, June 3-14, 1992, Resolutions Adopted by the Conference, U.N. Doc A/CONF.151/26/Rev.1 (June 14, 1992) [hereinafter Agenda 21].

83. Id.

84. Id. ch. $2, \S 10(\mathrm{~d})$.

85. Id. ch. $2, \S 2$. 


\section{(i) Programme Area 1: Promoting Sustainable Development Through Trade}

In its basis for action, Program Area A of Chapter 2 recognized that an open, equitable, secure, non-discriminatory and predictable multilateral trading system that is consistent with the goals of sustainable development will lead to the optimal distribution of global production in accordance with the principle of comparative advantage. ${ }^{86}$ This would in turn benefit all trading partners. It also acknowledged that improved market access for the exports of developing countries, in conjunction with sound macroeconomic and environmental policies, would have a positive environmental impact and therefore make an important contribution to the achievement of sustainable development. $^{87}$

Regarding commodity markets, Program Area A of Chapter 2 precisely identified the prevalence of very low and declining real prices for most commodities in international markets, and the resulting contraction in commodity export earnings for many producing countries. ${ }^{88}$ It has pointed out that the ability of developing countries to mobilize resources for sustainable development may be impaired by low commodity prices and by tariff and non-tariff impediments, including tariff escalation, which would limit their access to export markets. ${ }^{89}$ It has urged the removal of the existing distortions in international trade. ${ }^{90}$ This would require substantial and progressive reductions in the support and protection given to the agricultural sector by developed countries. ${ }^{91}$ This would also have to be done in other industries and sectors in order to avoid inflicting large losses on the more efficient producers, especially in developing countries. ${ }^{92}$ It has pointed out that trade liberalization must be pursued on a global scale across economic sectors if it is to contribute to sustainable development. ${ }^{93}$

Agenda 21 laid out the problems associated with the integration of environmental policies and trade issues. It stated that the growth in international trade had been "unevenly spread, and only a limited number of developing countries have been capable of achieving appreciable growth in their exports." $" 94$ Furthermore, protectionism and unilateral trade policy actions "continue to endanger the functioning of an open multilateral

86. Id. ch. $2, \S 5$.

87. Agenda 21, supra note 82.

88. Id. ch. $2, \$ 7$.

89. Id.

90. Id

91. Id

92. Agenda 21, supra note 82.

93. Id.

94. Id. ch. $2, \S 8$. 
trading system, affecting particularly the export interests of developing countries." 95 As a result of this issue, the Agenda explicitly linked trade liberalization with the "development possibilities of developing countries," and stated that trade liberalization would provide "greater security and predictability to the international trading system."

Programme Area A set four objectives for governments, taking into account the results of the Uruguay Round which was underway at the time. ${ }^{97}$ These were firstly the promotion of an "open, non discriminatory and equitable multilateral trading system;"98 secondly, an improvement in market access for developing countries; ${ }^{99}$ thirdly, to take measures to improve the functioning of international commodity markets; ${ }^{100}$ and finally to "promote and support policies, domestic and international, that make economic growth and environmental protection mutually supportive."101

\section{(ii) Programme Area 2: Making Trade and Environment Mutually Supportive}

Agenda 21 recognized that environment and trade policies should be mutually supportive. It outlined a number of principles and courses of action which may achieve this goal. ${ }^{102}$

Chapter 2 suggested that the GATT, the UN Conference on Trade and Development (hereinafter "UNCTAD"), as well as "other relevant international and regional economic institutions" undertake "adequate studies" into the trade and environment relationship. ${ }^{103}$ It stated that the causes of environmental/developmental problems should be dealt with in a way that "avoids the adoption of environmental measures which result in unjustified restrictions on trade."104 Similarly, environmental regulations themselves should not constitute an "arbitrary or unjustifiable . . . restriction on trade." ${ }^{105}$ It specifically stated that the special economic/environmental situation of developing countries should be "borne in mind" when environ-

\footnotetext{
95. Id.

96. Id.

97. Agenda 21, supra note 82, ch. 2, \$9.

98. Id. ch. 2, \$9(a).

99. Id. ch. 2, \$9(b).

100. Id. ch. $2, \S 9$ (c).

101. Id. ch. $2, \S 9$ (d).

102. Agenda 21, supra note 82, ch. 2, \$22.

103. Id.

104. Id. ch. 2, \$22(d).

105. Id. ch. 2, \$22(f).
} 
mental standards are being developed. ${ }^{106}$ Finally, the use of unilateral trade actions when environmental issues are outside the jurisdiction of importing countries should be avoided. ${ }^{107}$

(iii) Programme Area 3: Providing Adequate Financial Resources to Developing Countries

Agenda 21 asserted that "[m]any developing countries have experienced a decade long situation of negative net transfer of financial resources." 108 The result of this has been that "domestically mobilized resources had to be transferred abroad instead of being invested locally in order to promote sustainable development."109 Agenda 21 noted that "the reactivation of development will not take place without ... solutions to the [problem] of external indebtedness." "10

(iv) Programme Area 4: Encouraging Economic Policies Conducive to Environment and Development

Agenda 21 has repeatedly stressed the importance of sound economic policies which take into account the interests and concerns of developing countries, and the need to promote positive action which supports the efforts of least developed countries to halt their marginalization in the world economy. ${ }^{111}$ It has also called upon developed countries to provide developing countries with increased technical assistance for building the capacity of those nations to design and implement economic policies, to increase the efficiency of their tax systems and to promote entrepreneurship. ${ }^{12}$

\section{(v) The Commission on Sustainable Development}

The Commission on Sustainable Development (hereinafter "CSD") was created to monitor the implementation of Agenda 21 and to integrate the roles of different actors in the linking of environment and development. ${ }^{113}$ Deriving its authority from the Rio Declaration, the CSD was

106. Id. ch. $2, \S 22(\mathrm{~g})$.

107. Agenda 21, supra note 82, ch. 2, \$22(i).

108. Id. ch. $2, \S 23$.

109. Id.

110. Id. ch., $\$ 24$.

111. Id. ch. 2, 37.

112. Agenda 21, supra note 82, ch. $2, \S 38$.

113. Id. ch. $38, \S 11$. 
established in accordance with Article 68 of the UN Charter. ${ }^{114}$ It is required to report to the Economic and Social Council in the context of the Council's role under the UN Charter vis-à-vis the General Assembly. ${ }^{115}$ Its mandate included a requirement to "monitor progress in ... facilitating ... the transfer of environmentally sound technologies ... . to developing countries on favorable terms." 116

While its scope and jurisdiction are broad, the tremendous responsibilities assigned to the CSD far exceed the modest resources it has for implementing them. ${ }^{117}$ Furthermore, it was not given any power or authority with which to discipline member states who failed to comply with Agenda 21. As a result of these two issues, the CSD has little influence over the governing bodies of international organizations such as the World Bank Groups and the World Trade Organization (hereinafter "WTO"). Furthermore, the submission of country reports to the CSD is done on a voluntary basis, and the decision about what material to include in them is entirely discretionary. Not surprisingly, these reports tend to be long on self-congratulation and short on substantive analysis of remaining challenges. ${ }^{118}$

\section{AN ASSESSMENT OF THE RIO DECLARATION AND AGENDA 21: RHETORIC AND REALITY}

This section will provide a critique of the approaches to trade and environmental issues that Agenda 21 adopted. Particular attention will be given to the situation of developing countries in the sustainable development context.

\section{A. Lack of Specificity in Agenda 21 Commitments}

Progress on most of the issues linking trade and sustainability in Agenda 21 has been disproportionate to the consensus that was reached during the Earth Summit. Agenda 21 established a program of action by which the international community might achieve sustainable development. Although it contains the detailed agreement of over 170 countries to pursue the goal of sustainable development, it is largely hortatory and recommendatory in nature, and does not purport to bind UNCED participants to

114. Id.

115. Id.

116. G.A. Res., U.N. Doc. A/RES/S-19/2 par. 88 (Sept.19, 1997).

117. HUNTER, supra note 41 , at 399.

118. Id. at 402 . 
particular actions. ${ }^{119}$ The real significance of Agenda 21 lies in the implementation of its principles and programmes according to the specific commitments of the parties. However, over ten years after the adoption of this noble document, there are areas where the performance of developed countries has lagged far behind their promises. The gap between rhetoric and reality in promoting sustainable development has been widened. The implementation of Agenda 21 is more urgent than ever.

\section{B. Lack of Financial Resources (Agenda 21, Ch. 33)}

It has been estimated that developing countries will need approximately US\$600 billion per annum for the implementation of Agenda 21, of which $\$ 125$ billion will come from donor countries. ${ }^{120}$ This US $\$ 125$ billion funding commitment is in addition to the existing flow of Official Development Assistance (hereinafter "ODA") which has been estimated at about US $\$ 80$ billion. $^{121}$ Thus a total of $\$ 200$ billion per year has been committed to help developing countries achieve sustainable development. Developed countries were committed to contribute ODA targeted at 0.7 percent of GNP with no deadlines. ${ }^{122}$ Not only have the financial commitments of developed countries failed to materialize, but ODA has fallen drastically since $1992 .{ }^{123}$ Although a target of $\$ 200$ billion per annum was set for the implementation of Agenda 21, the amount of money which has in fact gone into it is closer to zero. ${ }^{124}$ Instead of ODA continually increasing from the initial $\$ 80$ billion, as it normally used to at the rate of a few per cent a year, to an estimated $\$ 200$ billion, it has decreased to $\$ 35$ billion, less than half the original amount. ${ }^{125}$ Thus, with no binding obligation to act on the lofty promises made in Agenda 21, the financial commitment of developed countries has been minimal.

The Global Environmental Facility (hereinafter "GEF") is a global environmental fund dedicated to the implementation of Multilateral

119. Jacob D. Werksman, Greening Bretton Woods, in THE EARTHSCAN READER IN SUSTAINABLE DEVELOPMENT 274, 281 (John Kirby et al. eds., 1995).

120. United Nations Department of ECONOMiC and Social affairs Division for Sustainable DeVelopment, Institutional Aspects of Sustainable Development in Nigeria (2005), available at http://www.un.org/esa/agenda21/natlinfo/countr/nigeria/inst.htm (last visited Oct. 18, 2005).

121. Khosla, supra note 81 , at 7 .

122. CHEE YOKE LING \& MARTIN KOHR, THIRD WORLD NETWORK, INTERNATIONAL ENVironmental Governance: SOME ISSUES from a DEVELOPINg COUNTRY PERSPECTIVE (2001), available at http:/www.twnside.org.sg/title/ieg.htm (last visited Oct. 18, 2005).

123. Id.

124. See Khosla, supra note 81 , at 7 .

125. Id. 
Environmental Agreements. ${ }^{126}$ Like Agenda 21, the GEF has not been receiving sufficient contributions from developed countries to make it effective. In Rio, the GEF received $\$ 5$ billion worth of commitments from developed countries. ${ }^{127}$ Of these, less than $\$ 2$ billion has actually materialized and this is entirely earmarked for climate change mitigation and biodiversity conservation, problems of interest to primarily the North. ${ }^{128}$ Developed countries should be more generous in their funding of the GEF on the basis of the principle of common but differentiated responsibility, and the needs of developing countries should be taken into account in the governance of the GEF.

\section{Transfer of Technology (Agenda 21 Ch 34)}

The demand of developing countries for the transfer of technology on concessional rates has not yet been satisfied. ${ }^{129}$ Although Agenda 21 included a chapter on the transfer of environmentally sound technology, cooperation and capacity building, no specific or firm commitments were made by developed countries. Agenda 21 mentioned that access to technology should be promoted, facilitated and financed appropriately, with an emphasis on technology cooperation and capacity building rather than outright transfer. ${ }^{130}$ However, developing countries remain concerned about the current dominance of multinational corporations in the area of technology. Transnational corporations are the primary holders of technologies and are not bound by any agreement to provide them on special and/or preferential terms to developing countries. The Trade-Related Aspects of Intellectual Property Rights (hereinafter "TRIPS") agreement has also severely impacted developing countries' ability to gain access to environmentally sound technology. ${ }^{131}$

\section{Capacity Building (Rio Principle 12, Agenda 212.38 (a-c))}

As noted above, little progress has been made on what Agenda 21 calls 'implementation issues' such as finance, access to environmentally sound

126. See generally Global Environment Facility, available at http:/www.gefweb.org/ (last visited Jan. 17, 2006).

127. See Khosla, supra note 81, at 7.

128. Id.

129. HUNTER, supra note 41 , at 402 .

130. Agenda 21 , supra note 82 , ch. $34, \$ 14($ b).

131. Jolita Butkevicine, United Nations Environment Programme, gats NEGOTIATIONS AND ISSUES FOR CONSIDERATION IN THE AREA OF ENVIRONMENTAL SERVICES FROM A DEVELOPMENT PERSPECTIVE ๆ 31 (2002). 
technologies and, perhaps to a lesser extent, capacity-building. ${ }^{132}$ Imbalances in the trade and environment agenda can only be addressed if sufficient attention is given to the development and implementation of such measures. ${ }^{133}$ Measures to achieve the objective of sustainable development as outlined in Agenda 21 should be implemented, taking into account the vulnerability of developing countries at the intersection of trade and environment. ${ }^{134}$

\section{E. Green Protectionism (Rio Principle 12; Agenda 21- 2.22 (c), 2.22(d), 2.22(f)}

Pro-trade and developing countries fear that trade restrictions for environmental purposes could open the door to green protectionism. Although cautioned by Agenda 21 against the use of unilateral trade measures for environmental purposes, several trade-environment disputes involving unilateral trade measures show that this trend is increasing. ${ }^{135}$ This trend undermines the spirit of Agenda 21 and Rio Principle 12.

\section{F. Food Security (Agenda 21 3.8(l))}

States committed to undertaking activities aimed at the promotion of food security place food self-sufficiency within the context of sustainable agriculture. ${ }^{136}$ Policies aimed at food self-sufficiency generally include trade policies such as subsidies and trade restrictions which need to be recognized by the WTO, as they risk being in conflict with GATT rules. ${ }^{137}$ Such policies have not in fact been implemented, nor has there been an examination of the circumstances under which such policies might be deemed "appropriate." 138

\section{G. Conclusions on the Rio Declaration and Agenda 21}

Agenda 21 is a comprehensive programme of action which has categorically and systematically addressed the concerns of developing countries in relation to trade and the environment with promises and commitments from the international community. However, the progress

132. Agenda 21, supra note 82 , ch. $2, \S 38(a)$.

133. Id. ch. 3, \$12.

134. Id. ch. $2, \S 39$.

135. Id. ch. 2, \$22(i).

136. Id. ch. $3,8(1)$.

137. INTERNATIONAL INSTITUTE fOR SUSTAINABLE DEVELOPMENT, RIO+5 SPEClaL FOCUS REPORT ON TRADE AND SUSTAINABLE DEVELOPMENT (MAR. 13-19, 1997) [hereinafter Rio +5].

138. Id. 
which has been made on the implementation of those commitments is inadequate. This is in large part because of a lack of political will in addressing the fundamental cross-sectoral concerns - issues of funding and technology transfer, trade, debt, poverty and inequities in wealth, the nature of international environmental institutions and the role of actors such as multinational corporations and NGOs. ${ }^{139}$ Many of these issues were on the agenda at Stockholm in $1972 .^{140}$ They were addressed by the World Commission on Environment and Development in 1987 and were on the agenda again in Rio in $1992,{ }^{141}$ yet it is doubtful whether we can claim to have moved in any significant way towards a resolution of these issues in the years since, despite the many conferences, declarations and commitments. $^{142}$

\section{NORTH-SOUTH ASPECTS OF THE UNITED NATIONS APPROACH TO TRADE AND THE ENVIRONMENT}

The UNCED was a significant step towards increasing global awareness of the relationship between environment and development. The aftereffects of UNCED continue to encourage a major global paradigm shift in the way that environmental and economic concerns are viewed by both industrialized and developing countries. ${ }^{143}$ As noted above, the real issues lurking behind the public debate on trade and environment at UNCED were the North-South relationship and economic development, the transfer of technology, declining terms of trade, intellectual property rights and equitable access to global resources.

Throughout the UNCED negotiations, the South asserted that its right to development must be an integral part of environmental protection measures. It views the present environmental degradation as directly linked unsustainable development models and lifestyles. However, environmental problems are not isolated from the development process, and an integrated approach is needed to address the issue of environmental protection. Developing countries argue that their right to development should be granted priority, and that environmental protection measures should not be in conflict with their economic growth and development. The special situation and needs of developing countries warrant special attention from the international community. Their capacity to comply with international standards needs to be considered. They need financial support from the North in order to be able to address environmental issues. For them,

139. ElLIOT, supra note 1 , at 99.

140. Id.

141. Id.

142. Id.

143. See Boer, supra note 79, at 103. 
poverty is the biggest threat to the environment. Indian Prime Minister Indira Gandhi expressed these concerns during the 1972 UNCHE in Stockholm:

On the one hand the rich look askance at our continuing poverty-on the other, they warn us against their own methods. We do not wish to impoverish the environment any further and yet we cannot for a moment forget the grim poverty of large numbers of people. Are not poverty and need the greatest polluters? $?^{144}$

This section will now outline some of the key issues developing countries face in the UN's approach to sustainable development.

\section{A. Lack of Financing and Systematic Unfairness in the Global Economic Order}

As was noted above, many of the financial commitments that developed countries undertook both in Agenda 21 and the Rio Declaration have not materialized. Furthermore, the development process of developing countries has been undermined and finally halted due to the unfairness of the global financial system. The inequities of current international economic relations, especially with regard to debt, trade and the transfer of technology have had serious consequences including a reverse flow of financial resources, brain drain and increasing backwardness in the scientific and technological capabilities of the Third World. ${ }^{145}$

In general, the global institutions dealing with international trade and finance tend to protect the interests of developed countries. Also, without a fair distribution of income between developed and developing countries, trade liberalization is unlikely to deliver economic and environmental benefits to developing countries.

It is therefore imperative that a new and equitable international economic order be established. Such an order must be conducive to the sustained and sustainable development of all countries, particularly developing countries, thereby creating the conditions necessary for global cooperation to protect the environment. ${ }^{146}$ Solutions to international environmental problems depend largely on the reform of the inequitable trading relationship between the North and the South.

144. P.M. Indira Gandhi, Address to the UN Conference on Human Environment (June 1972).

145. Chakravarthi Raghavan, Third World Takes Unified Position on Environment for Earth Summit, 1991, THIRD WORLD NETWORK FEATURES (on file with author).

146. Id. 
Despite the unprecedented focus on preserving the environment without sacrificing development, the Earth Summit bypassed an opportunity to discuss the reform of the international economic order. ${ }^{147}$ "Instead, the participants in UNCED largely accepted the current state of the international trading system and placed the onus for reform on environment policy." 148 It is vital to assess whether the present structures of global trade and finance are major roadblocks for developing countries in their efforts to fully realize the UNCED spirit of sustainable development.

Another aspect of the unfairness of the global economic order is the colonial style terms of trade between developed and developing countries. ${ }^{149}$ The primary commodities exported by developing countries in exchange for the goods and services of industrialized countries are constantly declining in value. This has resulted in tremendous income losses to developing countries, and has forced them to export their natural resources to maintain their balance of payments. The result is that they ruin their non-renewable resources by overexploiting them. Furthermore, these declines in commodity prices are contributing to the persistent debt crises of developing countries. These issues, combined with persistent balance of payments deficits are depriving developing countries of the finance necessary for sustainable development.

\section{B. The Concept of Common but Differentiated Responsibility}

As discussed above, the concept of common but differentiated responsibility was recognized in principle 7 of the Rio Declaration. ${ }^{150}$ This principle has been subsequently adopted by many international environmental agreements. ${ }^{151}$ However, the implementation of this principle has not been satisfactory. This section will now outline some theoretical and practical justifications for the substantive adoption of the principle, notwithstanding the lack of implementation to date.

147. Rodrigo J. Prudencio, Why UNCED Failed on Trade and Environment, $2 \mathrm{~J}$. ENV'T \& DEV. 2, 103 (1993).

148. Id.

149. Throughout the colonial period, outright exploitation by the developed countries has severely limited the capacity of developing countries to accumulate capital. Even after decolonization (in the 1950s, 1960s, and 1970s), the economic growth of the developing countries was slow and growth rates declined sharply. Under this pattem, costs of imports of developing countries rise faster than income from their exports. They are limited to exporting primary products to developed countries market in return for finished products.

150. Rio Declaration, supra note 52, princ. 7.

151. See, e.g., U.N. Conference on Environment and Development: Framework Convention on Climate Change, art. 3, May 9, 1992, U.N. Doc. A/AC/237/18 (Part II)/Add.1, 31 I.L.M. 851; The Montreal Protocol on Substances that Deplete the Ozone Layer, art. 5, Sept. 16, 1987, S. Treaty Doc. No. 10, 100th Cong., 1st Sess., 26 I.L.M. 1541. 


\section{Developed Countries are the Larger Polluters}

Developed countries, both in the present and historically, have tended to be larger polluters than developing countries. It would seem, therefore, that it is equitable and fair that they should take responsibility for cleaning up the results of their economic expansion. Their economic and technological superiority seem to justify a position as the leaders in setting standards for environmental protection.

\section{Capacity to Pay}

Developed countries, simply by their nature, have larger and more robust economies and financial resources. As a result, they would seem to have a better capacity to pay for environmental protection measures than developing countries. In other words, the proportion of their total income that developed countries would have to pay to undertake environmental protection measures, logically, is lower when compared with the proportion that developing countries would have to pay.

\section{Unsustainable Consumption Patters of the North}

Northern countries, despite their interest in environmental protection, continue their environmentally unsound patterns of living. ${ }^{152}$ By doing this, North is continuing to contribute to the deterioration of the natural environment. As a result, it would seem fair that either the North discontinues its present modes of consumption, or pay the costs of environmental protection measures caused by its consumption practices. ${ }^{153}$

\section{The Polluter Pays Principle and Developing Countries}

The aim of the Polluter Pays Principle is to ensure that the price of goods reflects the costs of producing those goods, including the costs associated with pollution, resource degradation and environmental harm. ${ }^{154}$ The goods which were not environmentally sustainable would therefore cost a great deal and so be less competitive. This would then act as an incentive for producers and consumers to choose more environmentally

152. Chris K. Mensah, The Role of the Developing Countries, in THE ENVIRONMENT AFTER RIO: INTERNATIONAL LAW AND ECONOMICS 33, 36 (Luigi Campiglio et al. eds., 1994).

153. Id. at 34.

154. ORgANIZATION FOR ECONOMIC COOPERATION \& DEVELOPMENT, RECOMMENDATION OF THE OECD COUNCIL ON GUIDING PRINCIPLES CONCERNING INTERNATIONAL ECONOMIC ASPECTS OF ENVIRONMENTAL Policies, C (72) 128 (May 26, 1972); For details, see OECD DocumENT: JoINT

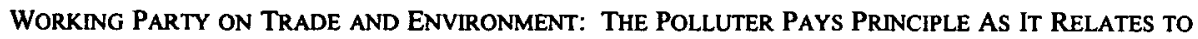
INTERNATIONAL TRADE, COM/ENV/TD (2001), available at http://www.olis.oecd.org/olis/2001 doc.nsf/LinkTo/com-env-td(2001)44-final (last visited Jan. 17, 2006). 
friendly products. In this sense, it seems to be consistent with the concept of common but differentiated responsibilities, in that it recognizes that countries that pollute more should bear the cost of undertaking environmental protection measures.

This principle has already been accepted by many bilateral and multilateral resolutions and declarations, and was confirmed by principle 16 of the Rio Declaration. ${ }^{155}$ However, the Polluter Pays Principle has the potential to impose disproportionate burdens on developing countries that lack pollution control infrastructure, financial resources and environmentally friendly technology necessary to develop and implement new strategies to reduce their pollution. As a result, they may find it difficult to bring their pollution levels down to or below those required by national and international pollution standards. This would require substantial financial resources, which could potentially be either raised through direct assistance, or by reducing trade barriers to exports from developing and leastdeveloped countries to the markets of developed countries.

Another issue for developing countries is their tendency to follow the traditional development path of developed countries which will be unsustainable. They are dependent on the use of obsolete and/or unsustainable technologies which are barriers to producing environmentally friendly products. Once again, the mitigation of this issue largely depends on the efforts of developed countries to either engage in the transfer of finance and technology, and/or the removal of trade barriers. Developing countries should be given preferential treatment with respect to access to financial resources and their implementation obligations must be based on the principle of common but differentiated responsibility obligations.

\section{The Intergenerational and Intragenerational Equity Principles}

The principle of intergenerational equity has become fundamental to the promotion of sustainable development. The principle outlines the responsibility of each generation to be fair to future generations in the use they make of their natural and cultural resource base. The intergenerational equity principle on the other hand refers to fair dealing in the consumption and exploitation of resources among and between members of the present generation. ${ }^{156}$

The Stockholm Declaration recognized these principles, and stated in principle 2 that "the natural resources of the earth including the air, water,

155. Rio Declaration, supra note 52, princ. 16.

156. Gregory F. Maggio, Inter/intra-generational Equity: Current Applications under International Law for Promoting the Sustainable Development of Natural Resources, 4 BUFF. ENVTL. L.J. 161 (1996-97). 
land, flora and fauna ... must be safeguarded for the benefit of present and future generations." 157

The Rio Declaration reaffirmed these principles, and stressed that the "right to development must be fulfilled so as to meet developmental and environmental needs of present and future generations." 158

The unsustainable consumption patterns of developed countries were recognized in Agenda 21, stating that "the unsustainable pattern of consumption and production, particularly in industrialized countries . . . is a matter of grave concern." However, it should be recognized that developing countries are also partly responsible for the unsustainable exploitation of natural resources. That being said, their unsustainable consumption patterns are the result of a lack of infrastructure and an inability to fulfill even their basic needs. As the World Commission on Environment and Development noted, "[a] world in which poverty and inequity are endemic will always be prone to ecological and other crises.",160

The notion of common but differentiated responsibilities is closely related to inter and intergenerational equity. They all recognize the significance of the partnership between developed and developing countries in addressing environmental protection issues. As Gregory F. Maggio argues, "it introduces the issue of equity between the North and South over the issue of cost based on responsibility for past environmental degradation and ability to pay for clean-up and future protection."161

Despite the recognition of the common but differentiated responsibility principle, and the principles of inter and intergenerational equity by the legal instruments dealing with sustainable development, the international community has done little to assist in the realization of these principles "beyond mere pronouncements in the preambles of treaties and other documents." 162 By way of example, the United States has issued a written statement at the UNCED rejecting any interpretation that would imply recognition of or acceptance by the US of any international obligations or liabilities, or any diminution in the responsibilities of developing countries. ${ }^{163}$

157. Stockholm Declaration, supra note 11, princ. 2.

158. Rio Declaration, supra note 52, princ. 3.

159. Agenda 21, supra note 82, ch. 4, \$3.

160. WORLD COMMISSION ON ENVIRONMENT AND DEVELOPMENT, OUR COMMON FUTURE 87 (1990).

161. Maggio, supra note 156, at 206.

162. Id.

163. Agenda 21, supra note 82 . 


\section{E. The Precautionary Principle}

Principle 12 of the Rio Declaration defines the precautionary principle as, "[w]here there are threats of serious or irreversible damage, lack of full scientific certainty shall not be used as a reason for postponing costeffective measures to prevent environmental degradation." 164 Although apparently reasonable, this phrase seems to be somewhat ambiguous. In particular, the definition of "serious" is clearly subjective and contextual. What developed countries consider serious, developing countries might consider insignificant, and vice versa. Environmental standards also depend on the level of economic development of a country. The level of environmental standards which are valid for the most developed countries may be inappropriate, and impose heavy social costs on developing countries.

The precautionary principle is generally applicable in a situation where there is an existence of risk from an action and there is lack of scientific certainty on the effect of such an action on human health and the environment. Therefore, this principle requires a risk assessment before application. Invoking precaution in situations where there is no risk, or where there is no scientific basis for the perceived risk, may lead to undesired consequences, such as imposing disproportionate costs on society and business, stifling technological innovation, or creating unjustified trade barriers. ${ }^{165}$ For example, the European Commission has on several occasions used precautionary reasoning to impose bans on technologies despite an absence of evidence of harm. In 1985 the European Commission banned the use of all animal growth promotion hormones even though its own inquiry had concluded that the use of natural hormones posed no risk to human health. ${ }^{166}$

Furthermore, developing countries lack the scientific knowledge, financial resources and the technological base to adequately assess risks which may be necessary to the adoption of the precautionary measures. Developing countries' difficulties in implementing the precautionary principle have been recognized in many international instruments and provi-

164. Rio Declaration, supra note 52, princ. 12. For a detailed discussion on the status of this principle, see generally ARIE TROUWBORST, EVolution AND STATUS OF THE PRECAUTIONARY PRINCIPLE IN INTERNATIONAL LAW (2002). See also James Cameron, The Precautionary Principle in, TRADE, ENVIRONMENT AND THE MILLENNIUM 239-69 (Gary P. Sampson \& W. Bradnee Chambers eds., 2000).

165. ORganization FOR ECONOMIC COOPERATION \& DEVELOPMENT, JOINT WORKING PARTY ON TRADE AND ENVIRONMENT: UNCERTAINTY AND PRECAUTION: IMPLICATIONS FOR TRADE AND ENVIRONMENT, COM/ENV/TD 114/ FINAL (Sept. 5, 2002) [hereinafter JOINT WORKING PARTY ON TRADE AND ENVIRONMENT].

166. Appellate Body Report, European Communities-Measures Concerning Meat and Meat Products, WT/DS26/AB/R (Jan. 16, 1998). 
sions have been required to assist developing countries to address their implementation problems. ${ }^{167}$ Despite this, the implementation of these principles has been lacking, and the situation of developing countries has not improved.

There is also some concern that in the absence of scientific proof, the precautionary actions may be used as protectionist measures to exclude goods from domestic markets. ${ }^{168}$

\section{F. Trade-Related Environmental Measures (Rio Principle 12; Agenda 21 $2.22(i), 39.3(d))$}

The practice of using trade measures as environmental tools has created controversy among both trade supporters and developing countries who often condemn these measure as protectionist, extra-jurisdictional, ecoimperial and unilateral. Trade Related Environmental Measures may take the shape of bans on trade, which can be used as a tool pursuant to multilateral environmental agreements or unilaterally by a developed country. Various GATT and WTO panels' rulings on disputes involving trade sanctions for environmental purposes have only fuelled this controversy. $^{169}$

The use of trade sanctions in the context of production and process method (hereinafter "PPM") is on the increase. The 1999 Trade and

167. Agreement on the Application of Sanitary and Phytosanitary Measures, GATT Doc. MTN/FA Ii-AlA-4 (Dec. 15, 1993) in Final Act Embodying the Results of the Uruguay Round of Multilateral Trade Negotiations, GATT Doc. MTN/FA (Dec. 15, 1993), 33 I.L.M. 9 (1994). The WTO Agreement on the Application of Sanitary and Phytosanitary Measures (SPS Agreement) acknowledges the difficulties of developing countries in the preamble:

Developing country Members may encounter special difficulties in complying with the sanitary or phytosanitary measures of importing Members, and as a consequence in access to markets, and also in the formulation and application of sanitary and phytosanitary measures in their own territories." Articles 9 and 10 of the SPS Agreement contain specific provisions on technical assistance and special and differential treatment. These provisions take into account the financial, trade and development needs of developing countries.

Agreement on the Application of Sanitary and Phytosanitary Measures, Apr. 15, 1994, Agreement Establishing the World Trade Organization, Annex 1A, reprinted in Uruguay Round Trade Agreements, Texts of Agreements, Implementing Bill, Statement of Administrative Action, and Reguired Supporting Statements, H.R. Doc. No. 103-316, vol. 1, 103d Cong., 2d Sess. 1381 (1994).

168. JOINT WORKING PARTY ON TRADE AND ENVIRONMENT, supra note 165.

169. See United States - Restrictions on Imports of Tuna: Report of the Panel, GATT B.I.S.D 39th Supp. 155 (1993); United States - Restrictions on Imports of Tuna (II): Report of the Panel, GATT Doc. DS29/R (May 20, 1994), 33 I.L.M. 839 (1994). United States Prohibition of Shrimps and Certain Shrimp Products, WTO Doc. WT/DS58/AB/R (98-000) (Oct. 12, 1998). United States - Standards for Reformulated and Conventional Gasoline, WTO Doc. WT/DSS/AB/R (May 20, 1996), 35 I.L.M. 603 (1996). 
Development Report of UNCTAD, while criticizing the protectionist tendencies of developed countries, indicated that if the North reduced/ eliminated its protectionism, an extra $\$ 700$ billion in annual export earnings could be achieved in a relatively short time by a number of low technology and resource-based countries.

\section{G. Traditional Intellectual Property Rights (Agenda 21 15.4(g))}

In Agenda 21, parties made a commitment to recognize and foster the traditional methods and knowledge of indigenous people and their communities which are relevant to the conservation of biological diversity. They also committed to ensuring that those groups have the opportunity to participate in the economic and commercial benefits which are derived from such traditional methods and knowledge. The World Trade Organization TRIPs Agreement covers some of these areas, but it has seen some controversy regarding its ability to protect the rights and traditional knowledge of indigenous peoples. ${ }^{170}$ In fact, arguably, the WTO TRIPs Agreement may even encourage northern exploitation of traditional knowledge of indigenous communities in the south. For example, under the agreement, multi-national corporations may enter developing countries, learn their local knowledge, reproduce it in a laboratory, and patent it because it supposedly involves an "inventive step." "71 As a result, indigenous communities lose the ability to use their own traditional knowledge.

This outcome would seem to be inconsistent with the obligations that the parties to Agenda 21 undertook. Instead, a sui generis system, which grants rights to indigenous people and their communities, may constitute fulfillment of the Agenda 21 commitments regarding the sharing of benefits.

\section{H Biodiversity and Forest Conservation}

It was argued by the South that environmental priorities such as forest conservation and biodiversity were designed by the North to serve their own interests, and that the conditionality attached to those considerations might even be used by the North against the South to ensure that their domineering economic power remained unchallenged in the future. Concern was expressed about the way in which the resources of the developing world, such as tropical forests or species and biodiversity, have been deemed the "common heritage of mankind"; resources which developing

170. Agreement on Trade-Related Aspects of Intellectual Property Rights, Apr. 15, 1994, Annex 1C., 33 I.L.M. 1197 (1994).

171. Id. 
countries are now supposed to manage for the good of all. ${ }^{172}$ The South repeatedly made it clear that it could contribute to sustainable development only if it had adequate environmental space for its economic growth and development. Thus any solution to the environmental problem will have to begin by bridging the terms of trade gap between the South and the North. ${ }^{173}$ These issues of environmental space and economic development have become the foundation for the legal position of the South. ${ }^{174}$

\section{CONCLUSION}

The role of the $\mathrm{UN}$ is unique and indispensable in providing the global framework, context and forum required to enable other actors to contribute effectively and cooperatively to addressing common global concerns. ${ }^{175}$ Unfortunately, the UN has been marginalized from the main thrust of policymaking in areas such as international trade, development, finance and monetary issues. ${ }^{176}$

Developing countries seem to be better at representing their needs and demands in the UN than in Bretton Woods Institutions which have been accused of being undemocratic insofar as the participation of states and their decision-making is concerned. The UN and its declarations and principles are noble and are based on the equitable and developmental needs of developing countries. The UN has provided guidelines on sustainable development which address the trade-environment issues confronting developing countries. The principles and recommendations which have arisen under the UN may be used as a Magna Carta for the resolution of the present crisis with regard to the interrelationship between trade and the environment.

To make the UN system more effective and to make it a credible forum for resolving the trade-environment dichotomy, member states need to provide the UN with the financial and political support it needs to govern trade and environment related problems. There is a need to make the UN commitments and programmers (such as sustainable development, environmental agreements, social development, and financing for development) operational, and to ensure that WTO agreements and Bretton Woods Institutions are supportive of sustainable development. ${ }^{177}$ There should be

172. ELLIOT, supra note 1, at 174.

173. Rio +5, supra note 137.

174. Mensa, supra note 152.

175. MaUrice F Strong, From Stockholm to Rio: A Journey Down a Generation EARTH SUMMIT 9-A REFERENCE BOOKLET ABOUT UNCED 21 (1992).

176. Chakravarthi Raghavan, The United Nations at the Cross-Roads, THIRD WORLD NETWORK FEATURES, available at http://www.twnside.org.sg/title/un-ch.htm (last visited Jan. 17, 2006).

177. LING, supra note 122. 
cooperation and coordination among UN entities, Bretton Woods Institutions and the WTO. The roles of UNEP and CSD need to be evaluated and strengthened if they are to police the implementation of the principles of common but differentiated responsibility, additional financial resources and the transfer of environmentally sound technology. There should be a balanced and integrated approach to trade and sustainable development, based on a combination of trade liberalization, economic development and environmental protection.

Developing countries should not also have to bear the economic burden of environmental protection at the cost of their right to development. In fact, developing countries in the Earth Summit agreed to address the environmental commitments sought by the North in return for increased flows of new and additional financial resources and technical assistance. Developed countries, however, have failed to keep their promises. Developed countries should initiate to implement their commitments which have already been made to sustainable development. Failure to do so would further undermine the capacity of developing countries to address tradeenvironment issues confronting them.

The current gap between rhetoric and reality deeply threatens the process of international negotiation to which we are all so strongly committed. ${ }^{178}$ While UNCED established a process for achieving sustainable development, much of its success will depend upon the political will of the developed countries in particular. 